\title{
Effect of feeding yeast culture on ruminal fermentation and blood indicators of Holstein dairy cows
}

\author{
Petr Doležal $^{1}$, Jan Dvořáček ${ }^{2}$, Jan Doležal ${ }^{1}$, Jana Čermáková1, Ladislav Zeman ${ }^{1}$, \\ Katarzyna Szwedziak ${ }^{3}$ \\ ${ }^{1}$ Mendel University Brno, Faculty of Agronomy, Department of Animal Nutrition and Forage production, \\ Brno, Czech Republic \\ ${ }^{2}$ S.O.S. Skalice nad Svitavou, s.r.o., Skalice nad Svitavou, Czech Republic \\ ${ }^{3}$ University of Technology Opole, Poland \\ Received May 13, 2010 \\ Accepted September 21, 2010
}

\begin{abstract}
The experiment was conducted to evaluate the effect of yeast culture (Saccharomyces cerevisiae) supplementation on ruminal fermentation in 20 Holstein dairy cows divided into control and experimental groups, each group of 10 cows. The animals received a diet based on maize silage $(19 \mathrm{~kg})$, alfalfa silage $(15 \mathrm{~kg})$, meadow hay $(1.5 \mathrm{~kg})$, extracted rapeseed meal $(1 \mathrm{~kg})$ and concentrate mixture $(9.5 \mathrm{~kg})$. The diets were fed as a total mixed ration. The supplement of yeast culture Levucell ${ }^{\circledR}$ SC 20 (Saccharomyces cerevisiae - CNCM I-1077; min. content $\left.2 \times 10^{10} \mathrm{CFU} \cdot \mathrm{g}^{-1}\right)$ was added to the concentrate mixture in the ration fed to the experimental group of animals. The addition of yeast culture significantly $(P<0.01)$ increased ruminal $\mathrm{pH}$ but had no positive effects on the increased production of volatile fatty acids. The supplementation of yeast culture significantly $(P<0.01)$ increased numbers of protozoa in the rumen of dairy cows of the experimental group $(361.3 \pm 18.315)$ compared to the control group $(308.3 \pm 37.505)$. The addition of yeast culture significantly $(P<0.01)$ increased concentration of serum glucose, calcium, phosphorus, copper, zinc, magnesium and AST $(P<0.05)$. As compared to the control group $\left(4.948 \pm 0.0384 \mathrm{mmol}^{-1} \mathrm{l}^{-1}\right)$, the level of urea in the blood serum was significantly decreased $(P<0.01)$ in the experimental group of cows.

Our results show that the supplementation of Saccharomyces cerevisiae culture at recommended doses enhances ruminal fermentation which may have a positive effect on milk production and health status of Holstein dairy cows.
\end{abstract}

Saccharomyces cerevisiae, cows, rumen fluid, blood serum indicators

Yeasts and yeast cultures are frequently used as additives in diets of dairy cows at present. They have a positive influence on fermentation in the rumen, which helps to improve production health and productivity of animals.

Results from previous studies on the effect of yeasts on ruminal fermentation and productivity of dairy cows are often ambiguous. The most cited benefit of yeast cultures on ruminal digestion is support of the growth and activity of anaerobic, namely cellulolytic bacteria. Yeasts would utilize residual oxygen introduced into the rumen with feeds, thus contributing to maintain anaerobic environment (Calsamiglia et al. 2006). Moreover, by degrading lyotropic carbohydrates in the rumen, yeast cultures regulate the rate of fermentation, and also by stimulation of lactate-utilizing bacteria yeasts facilitate stabilization of the rumen $\mathrm{pH}$ and mitigate its frequent oscillations during the day (Williams et al. 1991). Stable rumen environment is a key factor for achieving optimum milk yields and a good health of animals. However, some authors did not observe any beneficial effects of yeast cultures on dry matter intake or on the milk production and its composition in dairy cows (Cooke et al. 2007). Neither the positive influence of yeast on the digestibility of feeds in the rumen was unambiguously corroborated.

Recent studies indicate that yeasts produce also certain low-molecular peptides that simulate the activity of some bacteria species in the rumen (Denev et al. 2007). However, to achieve a positive effect of yeasts on the production efficiency of dairy

Address for correspondence:

Prof. MVDr. Ing. Petr Doležal, CSc.

Mendel University Brno

Phone +420545133163

Zemědělská 1-3, 61300 Brno, Czech Republic

E-mail: dolezal@mendelu.cz

http://www.vfu.cz/acta-vet/actavet.htm 
cows, it is necessary to choose an adequate preparation because not all yeast strains can stimulate digestion in the rumen (Pinos-Rodríguez et al. 2008). The efficiency of yeast cultures depends among other factors also on the conditions of cultivation, on the concentration of live yeast cells (CFU) as well as on the dose of the culture used (Doležal et al. 2006). Strusinska et al. (2003) found a positive influence of added yeast cultures, mineral and vitamin supplements on selected biochemical indicators in the blood of dairy cows. Similarly, Nursoy and Baytok (2003) observed a beneficial influence of yeast culture on ruminal digestion, and production efficiency of cows, whereas the concentrations of analyzed blood metabolites were similar for cows that consumed diets. Nevertheless, none of the published studies demonstrated a negative effect of yeast culture on ruminal digestion or animal health.

The aim of this study was to assess the effects of the yeast culture supplement in a total mixed ration (TMR) on some biochemical indicators of ruminal fermentation and selected blood indicators of highly producing dairy cows.

\section{Materials and Methods}

The experiment included 20 dairy cows of Holstein breed which were divided by ten into two equal groups with respect to productivity, number of lactations and live weight. The experimental period lasted 150 days. Cows were housed in a free-stall barn and fed $3 \times$ daily the same TMR with the experimental group receiving addition of the yeast culture Levucell ${ }^{\circledR}$ SC 20 (Saccharomyces cerevisiae-CNCM I-1077) in diet at a dose of $1 \mathrm{~g}$ per animal and day. The yeast preparation contained $80 \%$ of live dried organisms of Saccharomyces cerevisiae) and $14 \%$ of devitalized cells with the minimal guaranteed concentration of $2 \times 10^{10} \mathrm{CFU} \cdot \mathrm{g}^{-1}$. The control group of cows did not receive any yeast supplement.

The components, chemical composition and nutritional value of diets/feeding rations are presented in Table 1. Feed leftovers were removed before each feeding. Cows were milked in a milking parlour 2-times daily.

Samples of rumen fluid were taken from the cows of both groups by oesophageal probe using a method described by Dvořák (1994) within $3 \mathrm{~h}$ after feeding, during the $4^{\text {th }}$ month of the experiment. The rumen fluid was analyzed for the total content of volatile fatty acids (VFA), relative \% ratio of acetic, propionic and butyric acids, $\mathrm{pH}$ value, abundance of infusorians and ammonia content. Volatile fatty acids were measured by the gas chromatography method and the ammonia content was ascertained by the AOAC method (1980). The total content of infusorians was established according to a method described by Dvořák (1994). Blood was sampled by tapping from vena caudalis mediana into single-use test tubes without addition of anticoagulants to obtain blood serum from which serum urea, asparate aminotransferase (AST) and lactate dehydrogenase (LDH) were subsequently established. The biochemical indicators were established on an automated analyzer Model Reflovet Plus by using standard procedures in the laboratory of the Mendel University Brno. For analysis of glucose in a blood the heparin and sodium chloride were added to the test tubes.

The concentrations of macroelements - calcium $(\mathrm{Ca})$, phosphorus $(\mathrm{P})$, magnesium $(\mathrm{Mg})$ and trace elements - copper $(\mathrm{Cu})$, zinc $(\mathrm{Zn})$, manganese $(\mathrm{Mn})$ and selenium $(\mathrm{Se})$ were analyzed from the EDTA's plasma in the laboratory of the Mendel University Brno.

Results were statistically analyzed using the multi-factor analysis of variance (Snedecor and Cochran 1989) and by a subsequent verification based on Tukey Test.

\section{Results and Discussion}

Chemical composition and nutritional value of TMR are presented in Table 1. The concentration of crude fibre in $1 \mathrm{~kg}$ of dry matter was $16.80 \%$, which corresponds to the physiological requirement and production efficiency of dairy cows. With higher fibre contents in feeding rations, or at the introduction of low-quality feeds, intestinal digestion is reduced, rumen motoric activity is slowed down. The soluble form of $\mathrm{N}$ constituted $27.13 \%$ of total N-substances. The degradability of crude protein in the rumen was lower $(57.09 \%)$ and apparently connected with higher content of protected nitrogen. The advantage of TMR is a favourable proportion of degradable fibre $(28.10 \%)$. The content of fat $(4.99 \%)$ and the total content of starch $(27.87 \%)$ are in line with the recommendations. Somewhat higher is the value of starch degradability $(72.55 \%)$, which apparently results from the higher proportion of production mixture in the feeding ration $(9.5 \mathrm{~kg})$ and hence a higher amount of starch. Long-term feeding of this diet entails a possible risk of rumen 
Table 1. Composition and nutritional value of the total mixed ration

Ingredients

Corn silage $(\mathrm{kg})$

Alfalfa silage $(\mathrm{kg})$

Meadow hay $(\mathrm{kg})$

Extracted rapeseed meal $(\mathrm{kg})$

Concentrate mixture $(\mathrm{kg})$ Amount

Composition of concentrate mixture

Soybean meal (\%)

Rapeseed meal (\%)

26.0

Malt sprouts (\%)

Wheat $(\%)$

Barley (\%)

$\mathrm{CaCO}_{3}(\%)$

$\mathrm{NaHCO}_{3}(\%)$

$\mathrm{NaCl}(\%)$

Mineral mixture (MKP) (\%)

Nutrients

Dry matter (DM) (\%)

Crude protein (CP) (\%)

Lyotropic proteins from CP $(\%)$

Soluble proteins from CP $(\%)$

Rumen protein degradability (RDP) (\%)

Fat (\%)

Crude fibre (\%)

Acid detergent fibre (ADF) (\%)

20.0

12.0

20.0

15.1

1.5

1.2

1.0

3.2

Neutral detergent fibre (NDF) $(\%)$

Lignin (\%)

$\mathrm{N}$ - free extractives (NFE) (\%)

Starch (\%)

Starch degradability (\%)

Metabolisable energy (ME) $\left(\mathrm{MJ} \cdot \mathrm{kg} \mathrm{DM}^{-1}\right)$

Netto energy for lactation (NEL) $\left(\mathrm{MJ} \cdot \mathrm{kg} \mathrm{DM}^{-1}\right)$

Table 2. Qualitative indicators of total mixed ration

\begin{tabular}{lr}
\hline Indicator & Amount \\
\hline Lactic acid $\left(\mathrm{g} \cdot \mathrm{kg} \mathrm{DM}^{-1}\right)$ & 25.75 \\
Acetic acid $(\mathrm{g} \cdot \mathrm{kg} \mathrm{DM}$ & -1 \\
Sum of acids $\left(\mathrm{g} \cdot \mathrm{kg} \mathrm{DM}^{-1}\right)$ & 10.26 \\
Alcohols $(\mathrm{g} \cdot \mathrm{kg} \mathrm{DM}$ & $-1)$ \\
Titrable water acidity $\left(\mathrm{mg} \cdot \mathrm{KOH} \cdot 100 \mathrm{~g}^{-1}\right)$ & 1.5 \\
Moulds $\left(\mathrm{CFU} \cdot \mathrm{g}^{-1}\right)$ & 740.0 \\
\hline
\end{tabular}
the production of total volatile fatty acids where most authors mention a physiological reference range of $80-120 \mathrm{mmol} \cdot \mathrm{l}^{-1}$ of rumen fluid. Most published findings on the effects of Saccharomyces cerevisiae supplementation have shown that total rumen VFA concentration was not affected. Our results (Table 3 ) show that the supplementation of yeast

acidosis if the mixture does not include buffer supplements. The concentration of ME and NEL is in accordance with the productivity of the cows.

Qualitative indicators of TMR are presented in Table 2. The total daily amount of silage acids received from TMR at a daily intake of 20 $\mathrm{kg}$ dry matter is $720 \mathrm{~g}$, which can be considered slightly higher because it represents on average $1.2 \mathrm{~g}$ of silage acids per $1 \mathrm{~kg}$ live weight; their molar concentration $\left(9.08 \mathrm{~mol} \cdot\right.$ head $^{-1} \cdot$ day $\left.^{-1}\right)$ is within a normal range. Titrable water acidity $\left(740 \mathrm{mg} \mathrm{KOH} \cdot 100 \cdot \mathrm{g}^{-1}\right)$ corresponds to the total acidity in spite of its slightly exceeding the recommended value for TMR (700 $\left.\mathrm{mg} \mathrm{KOH} \cdot 100 \cdot \mathrm{g}^{-1}\right)$. The content of alcohol in $1 \mathrm{~kg}$ of TMR dry matter corresponds with the quality of used conserved feeds.

The effect of yeast culture supplement on the biochemical indicators of ruminal fermentation in dairy cows is presented in Table 3. The above results show that the $\mathrm{pH}$ value of rumen fluid in experimental cows is at the lower limit of the reference range (6.16) but is significantly higher $(P<0.01)$ than in the control cows (5.98). In this experiment, we corroborated the opinion of other authors (Guedes et al. 2008) about the influence of yeasts on the stabilization of $\mathrm{pH}$ value in the rumen fluid. On the other hand, this stabilization effect of yeast culture on the $\mathrm{pH}$ value was not proven by Nikkah et al. (2004).

The diet supplemented with Saccharomyces cerevisiae reduced the $\mathrm{pH}$ variation of ruminal fluid. Inconsistency can be seen also in the relation of yeasts and

\begin{tabular}{lr}
\hline Nutrients & \\
\hline Dry matter (DM) (\%) & 51.65 \\
Crude protein (CP) (\%) & 17.36 \\
Lyotropic proteins from CP (\%) & 8.01 \\
Soluble proteins from CP (\%) & 27.13 \\
Rumen protein degradability (RDP) (\%) & 57.09 \\
Fat (\%) & 4.99 \\
Crude fibre (\%) & 16.8 \\
Acid detergent fibre (ADF) (\%) & 19.02 \\
Neutral detergent fibre (NDF) (\%) & 30.24 \\
Lignin (\%) & 3.9 \\
$\mathrm{~N}$ - free extractives (NFE) (\%) & 52.7 \\
Starch (\%) & 27.87 \\
Starch degradability (\%) & 72.55 \\
Metabolisable energy (ME) ( MJ.kg DM & 11.97 \\
Netto energy for lactation (NEL) $\left(\mathrm{MJ}^{-1} \cdot \mathrm{kg} \mathrm{DM}^{-1}\right)$ & 6.96 \\
\hline
\end{tabular}


Table 3. Average characteristics of rumen fluid in Holstein cows $(\mathrm{n}=10)$

\begin{tabular}{lcccc}
\hline & \multicolumn{2}{c}{ Control group } & \multicolumn{2}{c}{ Experimental group } \\
& Average & SD & Average & SD \\
\hline $\mathrm{pH}$ & 5.98 & $\pm 0.083^{\mathrm{A}}$ & 6.159 & $\pm 0.153^{\mathrm{B}}$ \\
$\mathrm{NH}_{3}\left(\mathrm{mmol} \cdot \mathrm{l}^{-1}\right)$ & 9.092 & \pm 0.486 & 9.091 & \pm 0.777 \\
$\left.\mathrm{VFA} \mathrm{mmol} \cdot \cdot^{-1}\right)$ & 114.54 & $\pm 4.34^{\mathrm{B}}$ & 100.58 & $\pm 12.07^{\mathrm{A}}$ \\
$\mathrm{AA}(\%)$ & 54.10 & $\pm 2.74^{\mathrm{A}}$ & 60.30 & $\pm 2.49^{\mathrm{B}}$ \\
$\mathrm{PA}(\%)$ & 26.40 & $\pm 1.96^{\mathrm{B}}$ & 22.60 & $\pm 2.33^{\mathrm{A}}$ \\
$\mathrm{BA}(\%)$ & 19.50 & $\pm 1.50^{\mathrm{B}}$ & 17.10 & $\pm 0.83^{\mathrm{A}}$ \\
Infusorians (ths cfu $\left.\cdot \mathrm{ml}^{-1}\right)$ & 308.30 & $\pm 37.505^{\mathrm{A}}$ & 361.60 & $\pm 18.315^{\mathrm{B}}$ \\
\hline
\end{tabular}

VFA - volatile fatty acids; AA - acetic acid; PA - propionic acid; BA - butyric acid $\mathrm{A}, \mathrm{B}$ values differ at a significance level of $(P<0.01)$.

culture at the above mentioned concentration did not increase the production of VFAs, but experimental cows exhibited significantly lower VFA values $(P<0.01)$ than cows in the control group. Our results differ from Guedes et al. (2008), on the other hand, they are in line with conclusions published by Alshaikh et al. (2002), who either did not find any larger changes in the production of rumen VFAs or even detected a lower production of VFAs. Highly significant was the increase $(P<0.01)$ in the proportion of acetic acid and the decrease in the ratio of propionic and butyric acids compared to the control group. This finding is corroborated by observations of other authors (Nursoy and Baytok 2003), too. These results are confirmed by Guedes et al. (2008).

In contrast to our expectation, the yeast supplement had no effect on the concentration of ammonia in the rumen fluid; i.e. under the conditions of our experiment the yeast supplement did not result in a better utilization of ammonia. These results are in line with observations published by Guedes et al. (2008), but are not in accordance with results of Alshaikh et al. (2002). On the other hand, a significantly $(P<0.01)$ favourable effect of yeast culture supplement was demonstrated upon the average abundance of rumen infusorians. Obtained results suggest that yeast culture significantly stimulated metabolic activity of rumen infusorians (Figs 1 and 2), which is reflected in their increased counts. Figs 1 and 2 show the significant effect of rumen fluid $\mathrm{pH}$ value on the content of infusorians. We can see significantly higher dependency $(r=0.919)$ of infusorians numbers reduction with $\mathrm{pH}$ value decreasing in rumen fluid of treated

Table 4. Biochemical indicators in the blood of cows $(n=10)$

\begin{tabular}{|c|c|c|c|c|}
\hline & \multicolumn{2}{|c|}{ Control group } & \multicolumn{2}{|c|}{ Experimental group } \\
\hline & Average & SD & Average & SD \\
\hline Urea $\left(\mathrm{mmol} \cdot 1^{-1}\right)$ & $4.948^{\mathrm{B}}$ & \pm 0.0384 & $4.807^{\mathrm{A}}$ & \pm 0.0566 \\
\hline Glucose $\left(\mathrm{mmol} \cdot \mathrm{l}^{-1}\right)$ & $2.237^{\mathrm{A}}$ & \pm 0.0261 & $2.278^{\mathrm{B}}$ & \pm 0.0269 \\
\hline $\mathrm{Ca}\left(\mathrm{mmol} \cdot \mathrm{l}^{-1}\right)$ & $2.273^{\mathrm{A}}$ & \pm 0.0210 & $2.328^{\mathrm{B}}$ & \pm 0.0327 \\
\hline $\mathrm{P}\left(\mathrm{mmol} \cdot \mathrm{l}^{-1}\right)$ & $2.062^{\mathrm{B}}$ & \pm 0.0435 & $1.978^{\mathrm{A}}$ & \pm 0.0266 \\
\hline $\operatorname{Mg}\left(\mathrm{mmol} \cdot 1^{-1}\right)$ & $1.024^{\mathrm{B}}$ & \pm 0.0304 & $0.957^{\mathrm{A}}$ & \pm 0.0362 \\
\hline $\mathrm{Cu}\left(\mu \mathrm{mol} \cdot 1^{-1}\right)$ & $11.01^{\mathrm{A}}$ & \pm 0.7021 & $12.12^{\mathrm{B}}$ & \pm 0.2948 \\
\hline $\mathrm{Zn}\left(\mu \mathrm{mol} \cdot 1^{-1}\right)$ & $15.53^{\mathrm{A}}$ & \pm 0.7900 & $17.36^{\mathrm{B}}$ & \pm 0.5173 \\
\hline $\operatorname{Mn}\left(\mu \mathrm{mol} \cdot 1^{-1}\right)$ & $0.415^{\mathrm{A}}$ & \pm 0.0508 & $0.54^{\mathrm{B}}$ & \pm 0.0338 \\
\hline $\operatorname{Se}\left(\mu \mathrm{mol} \cdot 1^{-1}\right)$ & $0.35^{\mathrm{A}}$ & \pm 0.0242 & $0.441^{\mathrm{B}}$ & \pm 0.0278 \\
\hline $\operatorname{AST}\left(\mu \mathrm{kat} \cdot 1^{-1}\right)$ & $0.609^{c}$ & \pm 0.1097 & $0.744^{\mathrm{d}}$ & \pm 0.1094 \\
\hline $\mathrm{LDH}\left(\mu \mathrm{kat} \cdot \mathrm{l}^{-1}\right)$ & 14.8 & \pm 1.4387 & 15.87 & \pm 0.887 \\
\hline
\end{tabular}

A, B - values differ at a significance level $(P<0.01),{ }^{\mathrm{c}, \mathrm{d}}$ - values differ at a significance level $(P<0.05)$ 


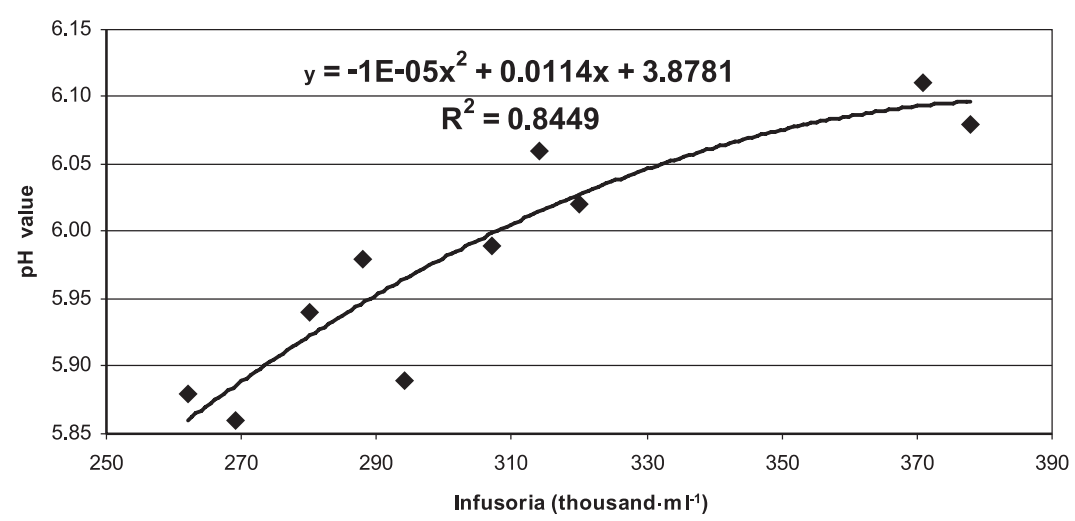

Fig. 1. The effect of $\mathrm{pH}$ value on the counts of rumen infusoria (control group)

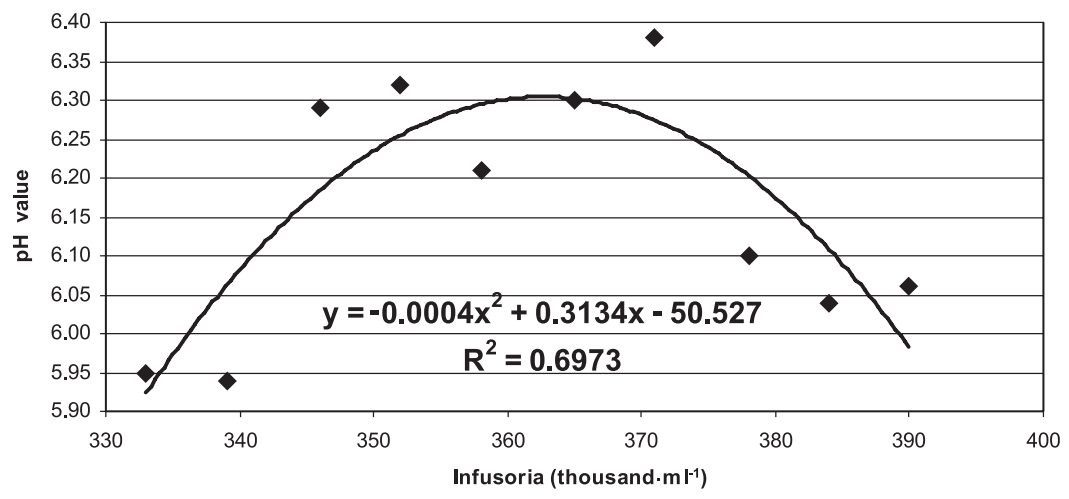

Fig. 2. The effect of $\mathrm{pH}$ value on the counts of rumen infusoria (experimental group)

cows (Fig. 1), however the dependency was weaker $(r=0.835)$. Similar relations were observed by Strzetelski et al. (1996).

The effect of yeast culture supplementation in TMR on the metabolic profile of blood of cows is presented in Table 4. Significant differences were recorded $(P<0.01)$ in the concentrations of glucose, urea and all mineral elements. Significantly lower concentration of urea in the blood serum of experimental cows $\left(4.807 \pm 0.566 \mathrm{mmol} \cdot \mathrm{l}^{-1}\right)$ as an indicator of nitrogen metabolism compared to the control group $\left(4.948 \pm 0.0384 \mathrm{mmol} \cdot \mathrm{l}^{-1}\right)$ suggests a better utilization of protein. Although the average values of blood urea exhibited a relatively high individual variability during long-term feeding, none of the two groups exceeded the reference concentration. Lower concentration of blood urea is often diagnosed in dairy cows in connection with a higher content of bypass protein in a diet or with a lower value of diet RDP in the rumen. Nikkah et al. (2004) did not corroborate the influence of yeast culture supplemented diet on concentrations of total protein, urea, glucose, cholesterol, triglycerides and mineral substances in the blood of cows. In both groups, the concentration of blood glucose was at the lower limit of reference value and in no case was the concentration of $3 \mathrm{mmol} \cdot \mathrm{l}^{-1}$ exceeded. Nursoy and Baytok (2003) mention similar, i.e. comparable concentration values of blood indicators in cows.

There were significantly higher $(P<0.01)$ concentrations of $\mathrm{Ca}, \mathrm{Cu}, \mathrm{Zn}, \mathrm{Mn}$ and $\mathrm{Se}$ in 
the blood of experimental cows, where as the contents of $\mathrm{P}$ and $\mathrm{Mg}$ were lower than in the control group.

Physiological limits of calcium $\left(2.25-2.99 \mathrm{mmol} \cdot \mathrm{l}^{-1}\right)$, phosphorus $\left(1.62-2.26 \mathrm{mmol} \cdot \mathrm{l}^{-1}\right)$, magnesium $\left(0.78-1.07 \mathrm{mmol}^{-1} \mathrm{l}^{-1}\right)$, zinc $\left(12.2-45.9 \mu \mathrm{mol} \cdot \mathrm{l}^{-1}\right)$ and manganese $(0.36-$ $\left.1.82 \mu \mathrm{mol} \cdot \mathrm{l}^{-1}\right)$ were observed while decreased physiological limits of copper $(12.6-$ $\left.18.90 \mu \mathrm{mol} \cdot \mathrm{l}^{-1}\right)$ and selenium $\left(0.50-1.90 \mu \mathrm{mol} \cdot \mathrm{l}^{-1}\right)$ were detected in the blood of cows of both groups. Blood zinc concentrations (control $15.53 \pm 0.79 \mu \mathrm{mol} \cdot \mathrm{l}^{-1}$, resp. $17.36 \pm 0.517$ $\mu \mathrm{mol} \cdot \mathrm{l}^{-1}$ ) in the experimental group were at a lower limit of the range. In spite of significant differences in the individual blood indicators, their concentrations are apparently not connected with the yeast culture supplementation but rather with the diet and with the individuality of cows, as works of other authors suggest, too (Nursoy and Baytok 2003). Similarly, the differences in the activity of AST and LDH enzymes indicate that the physiological limits of AST and LDH were not exceeded. According to Pechová et al. (2002), the activity of AST increases in dairy cows suffering from liver steatosis or in cows with disturbed energy metabolism. Its value is therefore very individually variable. Similarly, the activity of LDH enzyme in the blood serum did not exceed the reference volume and was apparently not affected by the addition of yeast culture.

The obtained results indicate that the supplementation of Saccharomyces cerevisiae culture at recommended doses has a positive effect on the ruminal digestion of Holstein dairy cows.

\section{Vliv zkrmování kvasinkové kultury na bachorovou fermentaci a krevní ukazatele krav holštýnského plemene}

Cílem příspěvku bylo posoudit prostřednictvím odebrané bachorové tekutiny a krve, vliv př́́davku testované kvasinkové kultury Levucell ${ }^{\circledR}$ SC 20 obsahující Saccharomyces cerevisiae (CNCM I- 1077) do směsné krmné dávky (TMR) dojnic na bachorové trávení a biochemické ukazatele krve krav holštýnského plemene. Kvasinková kultura byla přidána do krmné dávky pokusné skupiny krav v doplňkové krmné směsi v dávce $1 \mathrm{~g} / \mathrm{ks} / \mathrm{den}$. Krávy byly rozděleny po 10 ks do kontrolní a pokusné skupiny. Směsná krmná dávka byla založena na bázi kukuřričné siláže (19 kg), vojtěškové siláže (15 kg), lučního sena (1,5 kg), řepkového extrahovaného šrotu (1 kg) a doplňkové krmné směsi $(9,5 \mathrm{~kg})$. Vzorky bachorové tekutiny byly odebrány tři hodiny po nakrmení. Přídavek kvasinkové kultury statisticky významně $(P<0,01)$ zvýšil a stabilizoval hodnotu $\mathrm{pH}$ bachorové tekutiny. Ve srovnání s analyzovanými vzorky bachorové tekutiny kontrolní skupiny krav, přídavek hodnocené kvasinkové kultury neměl významný efekt na zvýšení obsahu těkavých mastných kyselin (TMK) v bachorové tekutině. V utilizaci amoniaku nebyl zjištěn mezi kravami experimentální $(9,091 \pm 0,777 \mathrm{mmol} / \mathrm{l})$ a kontrolní $(9,092 \pm 0,486 \mathrm{mmol} / \mathrm{l})$ skupiny žádný významný rozdíl. Doplnění kvasinkové kultury do krmné dávky signifikantně $(\mathrm{P}<0,01)$ zvýšilo počet infusorií v bachorové tekutině krav pokusné skupiny $\left(361,3 \pm 18,315 \mathrm{tis} \cdot \mathrm{ml}^{-1}\right)$ ve srovnání s kontrolní skupinou $\left(308,3 \pm 37,505\right.$ tis $\left.\cdot \mathrm{ml}^{-1}\right)$. Př́́davek kvasinkové kultury významně $(P<0,01)$ zvýšil v krevním séru obsah glukózy, $\mathrm{Ca}, \mathrm{P}, \mathrm{Cu}, \mathrm{Zn}, \mathrm{Mg}$ a také koncentraci AST $(P<0,05)$. Hodnota LDH nebyla mezi oběma skupinami krav významně odlišná $(P>0,05)$. Hladina sérové močoviny byla u pokusných dojnic $\left(4,807 \pm 0,0566 \mathrm{mmol} \cdot \mathrm{l}^{-1}\right)$ oproti kontrolní skupině $\left(4,948 \pm 0,0384 \mathrm{mmol} \cdot \mathrm{l}^{-1}\right)$ významně $(P<0,01)$ snížena.

Výsledky indikují, že přídavek kvasinkové kultury obsahující Saccharomyces cerevisiae CNCM I-1077 měl pozitivní efekt na bachorové trávení a stimulaci bachorové mikroflóry.

\section{Acknowledgement}

The study was financially supported from the Research programme No. MSM 6215648905 funded by the Ministry of Education, Youth and Sports of the Czech Republic. 


\section{References}

Alshaikh MA, Alsiadi MY, Zahran SM, Mogawer HH, Aalshowime TA 2002: Effect of feeding yeast culture from different sources on the performance of lactating holstein cows in Saudi Arabia. Asian-Aust J Anim Sci 15: $352-356$

AOAC (Association of Official Analytical Chemists) 1980: Official Methods of Analysis. 13th ed., AOAC, Washington, DC. $1018 \mathrm{pp}$

Calsamiglia S, Castillejos L, Busquet M 2006: Alternatives to antimicrobial growth promoters in cattle. In Garnworthy, P C, Wiseman, J 2005: Recent advances in animal nutrition 2005 Nottingham p. 129-167

Cooke KM, Bernard JK, West JW 2007: Performance of lactating dairy cows fed whole cottonseed coated with gelatinized starch plus urea or yeast culture. J Dairy Sci 90: 360-364

Denev SA, Peeva Tz, Radulova P, Stancheva N, Staykova G, Beev G, Todorova P, Tchobanova S 2007: Yeast cultures in ruminant nutrition. Bulg J Agric Sci 13: 357-374

Doležal J, Pyrochta V, Doležal P 2006: Yeast culture and its effect on ruminal fermentation in dairy cos. In Days of Nutrition and Veterinary Dietetics VI, Košice, pp. 75-78

Dvořák R 1994: Characteristics of fermentation processes in the rumen. In: Biotechnology in the feed industry. Research Institute of Animal Nutrition, Pohořelice, pp. 21-24

Erasmus LJ, Botha PM, Kistner A 1992: Effects of yeast culture supplement on production, rumen fermentation and duoedenal nitrogen flow in dairy cows. J Dairy Sci 75: 3056-3065

Guedes CM, Goncalves D, Rodrigues MAM, Dias da Silva A 2008: Effects of a Saccharomyces cerevisiae yeast on ruminal fermentation and fibre degradation of maize silages in cows. Anim Feed Sci Technol 145: 27-40

Nikkah A, Bonadaki MD, Zali A 2004: Effects of feeding yeast (Saccharomyces cerevisiae) on production performance of lactating Holstein dairy cow. Iranian J Agric Sci 35: 53-60

Nursoy H, Baytok E 2003: The effects of baker's yeast (Saccharomyces cerevisiae) in dairy cow diets on milk yield, some rumen fluid parameters and blood metabolites of dairy cow diets. Turk-Veterinerlik-ve-HayvanclkDergisi 27: 7-13

Pechová A, Illek J, Pavlata L 2002: Einwirkungen der Lebersteatose auf den Stoffwechsel bei Milchkühen. Wien Tierärztl Mschr 89: 325-332

Pinos-Rodríguez JM, Robinson PH, Ortega ME, Berry SL, Mendoza G, Bárcena R 2008: Performance and rumen fermentation of dairy calves supplemented with Saccharomyces cerevisiae or Saccharomyces boulardii. Anim Feed Sci and Technol 140: 223-232

Snedecor GW, Cochran WG 1989: Statistical Methods. $8^{\text {th }}$ ed., The Iowa State University Press.

Strusinska D, Iwanska S, Mierzejewska J, Skok A 2003: Effect of mineral-vitamin and yeast supplements on concentrations of some bichemical parameters in the blood serum of cows. Medycyna - Weterynaryjna 59: $323-326$

Strzetelski J, Maciejewicz J, Bilik K et al. 1996: Effect of new yeast on calf rearing, rumen fermentation and protozoa population in the rumen of young bulls. Roczniki Nauk Zootech 23: 1, 123-141

Williams PE, Tait CA, Innes GM, Newbold C J 1991: Effects of the inclusion of yeast culture (Saccharomyces cerevisiae plus growth medium) in the diet of dairy cows on milk yield and forage degradation and fermentation patterns in the rumen of steers. J Anim Sci 69: 3016-3026 